\title{
Research of the factor dependence of egg and egg products consumption in the subjects of the Russian Federation
}

\author{
Galina Sergeevna Bondareva, and Nikolay Sergeevich Bondarev \\ FSBEI HE Kuzbass State Agricultural Academy, 650056, st. Markovtseva, 5, Kemerovo, Russia
}

\begin{abstract}
Importance of consummating eggs and egg products in the diet of the population is determined by their high nutritional value. An egg contains a complete animal protein, it has consumer accessibility (both economic and physical) and prevalence in food markets regardless of the territory. The widespread availability (both assortment and price) of eggs and egg products to some extent can compensate for the deficit in consumption of other types of livestock products, which are often not available for socially vulnerable groups of the population with a low level of income. This food group is one of the most valuable products in the structure of rational consumption that meets the modern requirements of a healthy diet, which is reflected in the relevant Recommendations of the Ministry of Health of the Russian Federation [1]. The conducted research is based on the analysis of the main parameters of eggs and egg products' consumption. The emphasis is made on the study of statistical information on the number of the living population; the prevailing average per capita money income; consumer average retail prices for the specified food group; the level of consumption, its compliance with a rational level that meets modern requirements for healthy nutrition in equal subjects of the Russian Federation, both in the region, territory, republic, autonomous okrug, autonomous region, and in cities of federal significance: Moscow, St. Petersburg, Sevastopol. The result of the study was confirmation of the direct dependence of the reduction in the consumption of eggs and egg products as a result of a decrease in the population's income. The territorial aspect also indicated the existence of such dependence. All this allows us to assert that the fundamental factor affecting the level of consumption of eggs and egg products is the economic affordability of the food group, which depends on the income of buyers $[11 ; 13]$.
\end{abstract}

\section{Introduction}

In order to ensure the economic and physical accessibility of food, food security in the territories of the Russian Federation, it is definite that the price of an egg and other types of basic food products should vary depending on the average per capita monetary income of the population, its purchasing power. All this proceeds from a certain axiomatic relationship: the higher the income, the higher the prices for food, and the inverse 
relationship: the lower the income, the lower the price of food. Otherwise, there will be a territorial disparity in food supply.

The value of eggs and egg products in the diet of the population is explained due to the presence of balanced nutrients in them, in their properties, equal to milk and beef. So the energy value of $100 \mathrm{~g}$ of egg mass averages $157 \mathrm{kcal}$, which is comparable to $72 \mathrm{~g}$ of boneless beef, $44 \mathrm{~g}$ of pork or $350 \mathrm{~g}$ of milk $[2 ; 10]$. However, it should be noted that the costs of purchasing the specified set of products are not comparable and may exceed more than twice.

According to Russian Statistics Committee, for 2020 the average retail price of one egg in Russia was 6.38 rubles, while the amount of milk equivalent in energy was 23.4 rubles, boneless beef - 38.61 rubles, pork - 29.8 rubles [4]. In this connection, milk and products of its processing, meat and products of its processing, eggs, bread and bakery products, vegetables and fruits can be attributed to the main foodstuffs supporting the standard of living [3, p. 3]. The presence of such significance determines the relevance of the study.

\section{Basic Methods}

The research approach is implemented on the basis of statistical material of the constituent entities of the Russian Federation with the highest and lowest average per capita money incomes of the population in terms of the achieved values in terms of the following parameters: the average annual population, the level of per capita money income, the current level of average retail prices for eggs, the level of consumption of eggs and egg products, of the population with monetary incomes below the established value of the subsistence minimum, the level of consumption to the established rational norms of food consumption that meets modern requirements for a healthy diet. To confirm the importance of applying this approach, the authors methodically used the allocation of territories with significant opportunities for economic accessibility of food and, accordingly, territories where an inversely proportional situation is actually developing: in addition to the prevailing low average per capita money income, a high proportion of the population with money incomes below the subsistence minimum was noted.

As additional research methods in the presented article, the following are applied: economic and statistical, observation, graphic, synthesis, analysis methods. The empirical basis of the study was statistical information presented on the official website of the Federal State Statistics Service.

\section{Data and Primary Analysis}

From the standpoint of the designated study, the dynamics of the average annual number of population and the level of their incomes for equal subjects of Russia have been analyzed (Figure 1;2) [4]. 


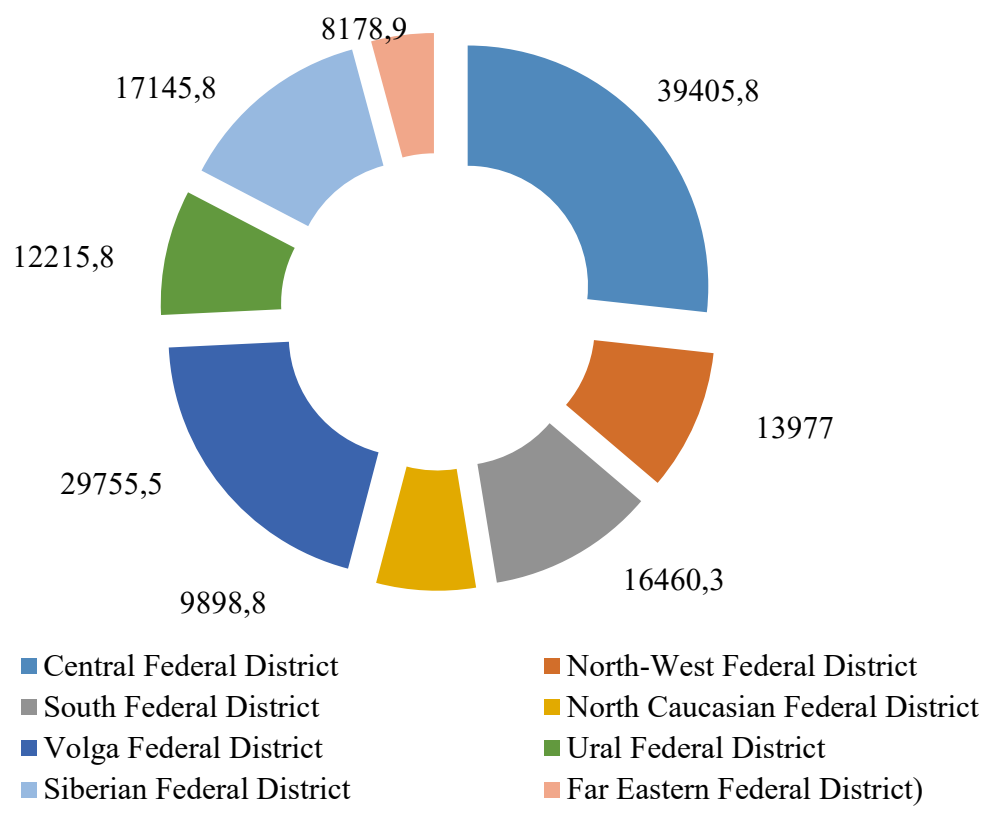

Fig. 1. Distribution of the average annual population of the Russian Federation by federal districts according to data for 2019 .

Analyzing the average annual population in the context of federal districts, it was determined that the largest share of residents is noted in the Central Federal District (26.8\%) and the Volga Federal District (20.3\%), while the Far Eastern Federal District has the smallest number of population in the presence of one. an increase of 8,178.9 million people in 2019 (5.5\% of the average annual population of Russia), against 6,174 million people in 2017.

The average per capita monetary income of the population, grouped by size (Figure 2), indicates that the most frequent distribution of the number series is concentrated within the amounts of 25,000-30,000 rubles; the peak of the distribution is 25,000 rubles, which is typical for 32 equal subjects of the Russian Federation out of 85.

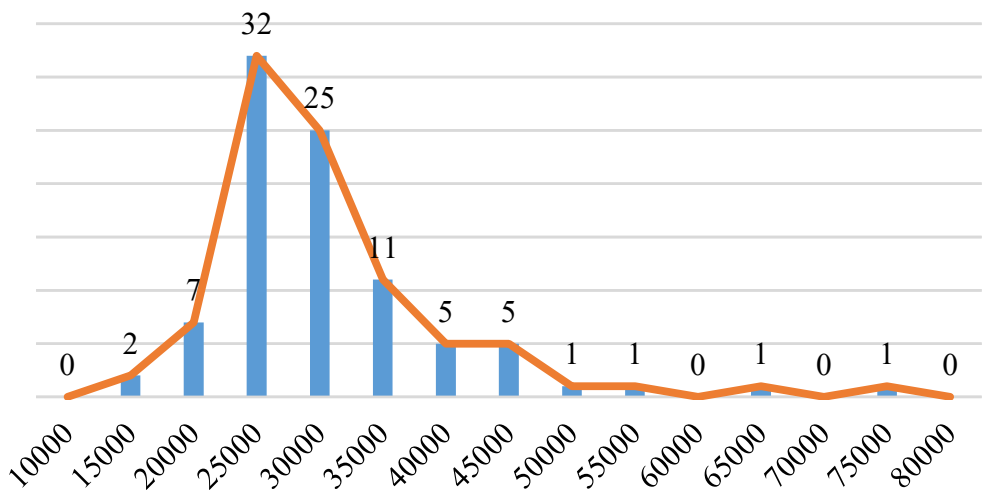

Fig. 2. Distribution of equal subjects of the Russian Federation by the level of per capita monetary income, units (01.01.2021). 
At the same time, the territories with the highest level of per capita money income according to the data for 2020 include the subjects of the Central, Northwestern and Far Eastern federal districts with the average value of the indicator in the amount of 47,224 rubles, 38,903 rubles and 38,550 rubles, respectively.

From the standpoint of assessing the economic accessibility of basic types of food for equal subjects of the Russian Federation based on the level of per capita money income, namely, the republics of Ingushetia and Tyva, within the established range of no more than 18,000 rubles, it is necessary to take into account the ratio of the prevailing price level for the specified food group, i.e. to study the consumer market for the group of food products "eggs and egg products".

\section{Results and discussion}

As the general features of the functioning of the consumer market by groups of food products, it is customary to single out the features inherent in the territories (Figure 3) [5, p. 67-68].

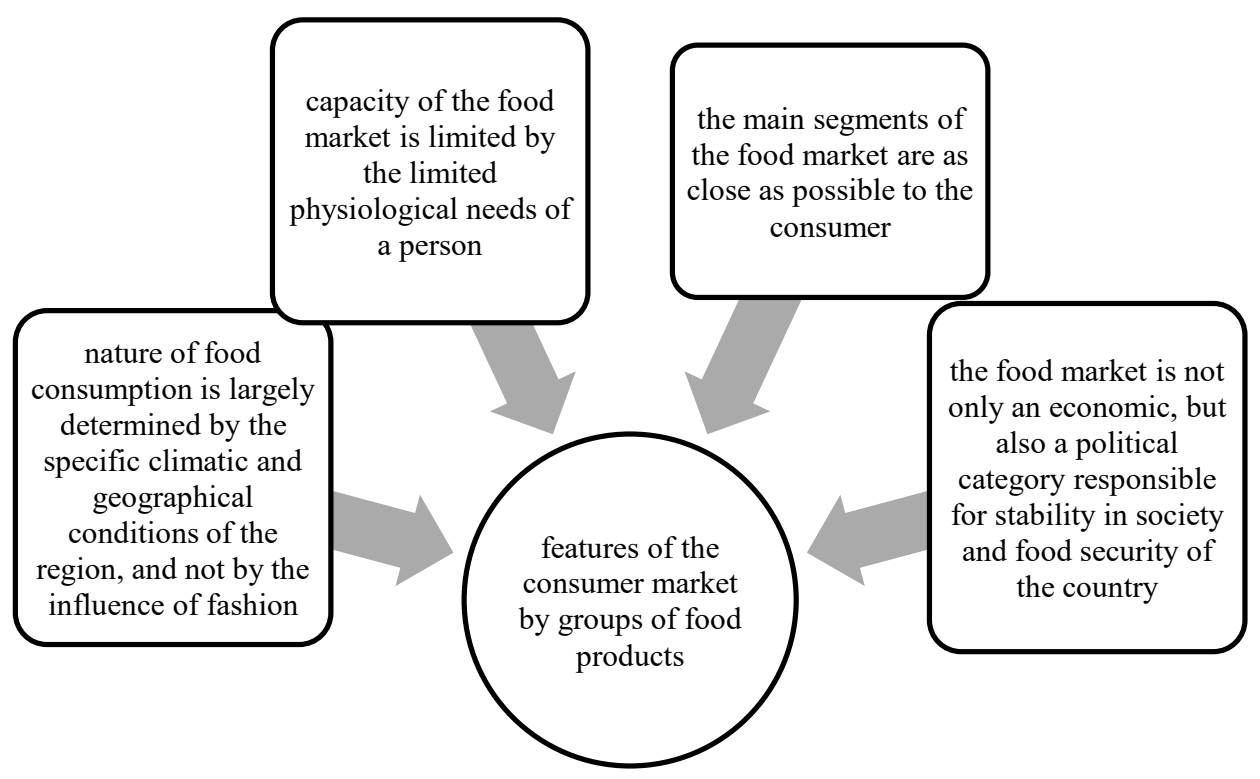

Fig. 3. Functioning features of consumer market by groups of food products.

Taking into account the specifics of the organization of activities in the production of eggs and poultry meat, it is necessary to focus on the importance of the natural and economic conditions of management. Often, the priority is precisely the territorial localization of production $[6 ; 8]$. The presence of a constant demand for this food group, year-round production capabilities with an organized sales market allow enterprises in this industry to almost completely eliminate the seasonality factor [7; 14].

Based on a statistical study, the subjects of the federation were identified with the lowest average per capita income (the Republic of Ingushetia (17,105 rubles) and the Republic of Tyva (17,582 rubles)) and with the highest level of average per capita monetary income (Chukotka Autonomous Okrug (89,059 rubles) and the Yamalo-Nenets Autonomous Okrug (RUB 88 579)). In other subjects of the federation with an average 
level of per capita money income, the values may vary, which makes it difficult to identify a trend. The median price level was determined as a reference indicator [9].

Analyzing the subjects of the federation designated as the object of research (with the lowest and highest level of per capita money income), it was determined that in the republics of Ingushetia and Tyva, the average retail prices for the food group "egg" amounted to 59.95 rubles and 63.56 rubles, in the Chukotka Autonomous Okrug and the Yamalo-Nenets Autonomous Okrug - 154.97 and 75.22 rubles, respectively (Figure 4).

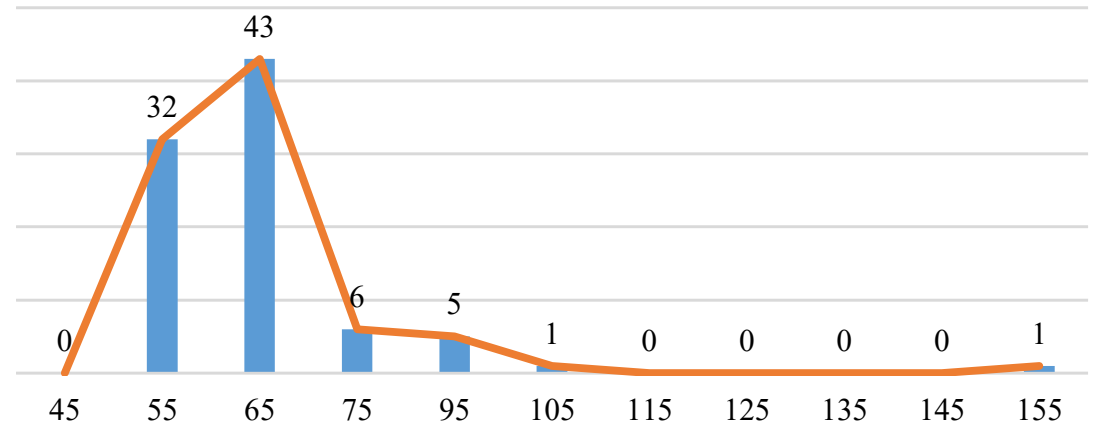

Fig. 4. Distribution of equal subjects of the Russian Federation based on the current level of average retail prices for an egg (as of 01/01/2020).

The existing price level on the food market for eggs, as a commodity group, indicates the establishment of the average retail price in January 2020 at 65.44 rubles per 10 pieces, with a minimum value of 46.37 rubles that was noted in the Republic of Mordovia.

Carrying out a similar study on the level of consumption of eggs by the population, the following data were obtained (Figure 5). The main groups are identified by the level of consumption: the population of 16 subjects of the Russian Federation consumes eggs at the level of 210 pieces, the population of 32 subjects -230 pieces, the population of 18 subjects - 250 pieces per capita. The consumption rate of eggs, based on the recommended rational standards, is 260 eggs per year, i.e. in 71 constituent entities of the Russian Federation, the population under-consumes the specified food group in accordance with the established border.

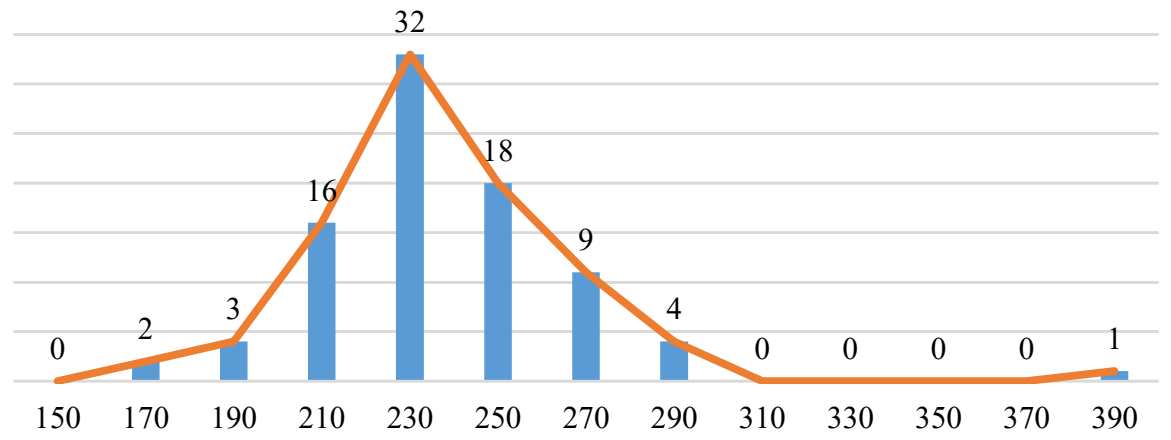

Fig. 5. Distribution of equal subjects of the Russian Federation by the level of egg and egg product consumption (as of 01/01/2020). 
The population of the republics of Ingushetia and Tyva consume 199 and 172 pieces per a household member, respectively. In turn, in the Chukotka Autonomous Okrug and the Yamalo-Nenets Autonomous Okrug, the population consumes 184 and 294 pieces, respectively; whereas the median consumption of eggs is at the level of 230 eggs.

As an indicator that strengthens the presented study, the proportion of the population with monetary incomes below the established value of the subsistence minimum in the respective regions is taken into account. So in the Republic of Tyva, the subsistence level is determined by the border of 8,846 rubles, in the Republic of Ingushetia - 10,571 rubles, while in the subjects with the highest level of income as the Chukotka Autonomous Okrug and the Yamalo-Nenets Autonomous Okrug - 24,875 rubles and 16640 rubles per capita. Regarding the proportion of the population with monetary incomes below the established value of the subsistence minimum, the most problematic situation was again noted in the Republic of Tyva and the Republic of Ingushetia, where the proportion of this population is critically high $-34.7 \%$ and $30.5 \%$, respectively. The statistics for the Chukotka Autonomous Okrug and the Yamalo-Nenets Autonomous Okrug are as follows: $8.7 \%$ and $5.6 \%$, respectively, with an average Russian value of $12.3 \%$ according to data in 2020 [4].

Low incomes of the population, a high proportion of the population with monetary incomes below the established value of the subsistence minimum (the Republic of Tyva is more than 1.3 of the total population), the underdevelopment of the consumer market for food product groups negatively affects the purchasing power of the population, the economic accessibility of basic food groups their physical availability.

Low economic opportunities of the population, the prevailing price level, its growth affect the constant decline in purchasing power [12]. In 2019-2018 alone, the population of the Republic of Tuva in the "egg and egg products" food group "lost" the opportunity to purchase more than 80 eggs per year (3048 eggs versus 2963 eggs, respectively). In the Yamalo-Nenets Autonomous Okrug, the situation is directly related - 11,735 pieces and 10192 pieces, i.e. +154.3 dozen eggs per year.

\section{Conclusion}

The revealed structure indicates the following statements:

- in the constituent entities of the federation with the lowest level of per capita money income, the consumption of eggs and egg products is in the under-consumption zone from the established rational norms of food consumption that meet modern requirements for a healthy diet - $260 \mathrm{pcs} / \mathrm{year} /$ person. The value of consumption in the Republic of Ingushetia was $76.5 \%$ of the rational nutritional norm; Tyva $-66.1 \%$, respectively.

- in the constituent entities of the federation with the highest level of per capita money income, the under-consumption of eggs and egg products is observed in the Chukotka Autonomous Okrug - 76 pcs. ( $70.7 \%$ of the rational consumption rate); while in the Yamalo-Nenets Autonomous Okrug, an over-consumption of eggs was noted, which amounted to 34 pcs. (113.1\% of the rational consumption rate).

Thus, the revealed trend confirms the axiomatic statement about the presence of a direct dependence of the consumption of eggs and egg products on economic factors: the average retail price and income of the population.

\section{References}

1. Order of the Ministry of Health and Social Development of the Russian Federation of August 19, 2016 No. 593n «On the approval of recommendations for rational norms of 
food consumption that meet modern requirements for healthy eating», https://www.rosminzdrav.ru/

2. Draft program "Development of poultry farming in the Russian Federation for 20102012 and for the period up to 2018-2020", http://www.mcx.ru/

3. T.V. Gomelko. Theoretical foundations of food market formation: monograph, 104 (2007).

4. Unified interdepartmental information and statistical system (EMISS): Federal State Statistics Service, www.fedstat.ru

5. O.P. Nikiforova, I.V. Antokhonova, Bullit. Of Buryat. state univ, 2, 60 (2010)

6. C. Currie, M. Hammon, American Planning Association, 1, 56 (2021)

7. M.F.a. Neves, A.W.b. Gray, C.E.c. Lourenço, F.A.d. Scott, Wageningen Academic Publishers, 1, 138(2021).

8. M. Clark, D. Tilman, Environmental Research Letters, 12 (6), 064016 (2017)

9. A. Mishra, A. Agarwal, Inderscience Publishers, 1, 107 (2021)

10. Y. Bai, R. Alemu, S.A. Block, D. Headey, W.A. Masters, Elsevier Ltd, 99, 101983 (2021)

11. S.D. Rathnayaka, S. Selvanathan, E.A. Selvanathan, Blackwell Publishing Ltd, 1, 97 (2021)

12. G. Giraud, M. Grasselli, (March 2021). Elsevier B.V., 183, 901 (2021)

13. N. Baral, B. Paria, B. Behera, P. Mishra, Elsevier Ltd, 21, 100296 (2021)

14. O. Kosenchuk, O. Shumakova, A. Zinich, S. Shelkovnikov, A. Poltarykhin, Colloids and Surfaces A: Physicochemical and Engineering Aspects, 10(5), 991 (2019) 